\title{
IMPACT OF SELECTED PROPERTIES OF RAW MATERIAL ON QUALITY FEATURES OF GRANULAR FERTILIZERS OBTAINED FROM DIGESTATES AND ASH MIXTURES
}

Marek Wróbel*, Jarosław Frączek, Marcin Jewiarz, Krzysztof Mudryk, Krzysztof Dziedzic

Department of Mechanical Engineering and Agrophysics, University of Agriculture in Krakow

*Corresponding author: marek.wrobel@ur.krakow.pl

\begin{tabular}{l}
\hline ARTICLE INFO \\
\hline Article history: \\
Received: September 2016 \\
Received in the revised form: \\
October 2016 \\
Accepted: November 2016 \\
\hline Key words: \\
biomass ash, \\
digestate, organic and mineral \\
fertilizer, \\
granular fertilizer
\end{tabular}

ABSTRACT
The paper presents the results of research, the objective of which was
to determine the impact of particle size distribution and density of
digestates and ash on density and tensile strength of granular fertilizer
obtained from mixtures of these substrates. Particle size distribution,
absolute density, envelope density and porosity of substrates were
determined. Granular fertilizers were made of clean substrates and
their mixtures. Envelope density of the obtained granulates was within
$0.81-1.88 \mathrm{~g} \cdot \mathrm{cm}^{-3}$. The determined compaction degree was within $3.65-$
10.12 . While, the compaction index IS of granulates made of mixtures
was within $0.5-0.55$ and was lower in comparison to IS of granulates
from digestates $(0.6)$ and ash $(0.76)$.

\section{Introduction}

A digestate is a by-product which was produced in a biogas plant in the process of anaerobic methane fermentation. Regardless the type, substrate in the fermentation process is subject to the following transformations: reduction of organic substance content, decomposition of odour generating compounds, fragmentation of solid particles, improvement of dehydration ability and fractional hygienization with considerably low losses of fertilizer components (Bavutti et al., 2014; Grinzi et al., 2012).

A degree of the mentioned transformations depends mainly on the content of organic substances in raw material, which are not subject to or subject only to a small extent to biodegradation in anaerobic conditions and on the conditions and duration of fermentation. From $30 \%$ to $60 \%$ of organic matter is decomposed. During anaerobic fermentation $80 \%$ of the substance which is degradable is transformed into biogas (Kowalczyk-Juśko and Szymańska, 2015).

Digestate which remains after the process includes: biomass of microorganisms which carry out the fermentation process, non-fermented organic compounds and mineral components. These substances are precious from the point of view of fertilization because they include $\mathrm{N}, \mathrm{P}, \mathrm{K}$ in the mineral form, which are directly available for cultivated plants. Moreover, the content of organic matter which is subject to mineralization is a source of 
nutrients and positively influences the physical and chemical properties of soils improving thus their productivity.

During the fermentation process, organic nitrogen compounds are transformed mainly to the ammonium phase $\left(\mathrm{N}-\mathrm{NH}_{4}\right)$ which is easily available for plants, which may constitute as much as $80 \%$ of the general nitrogen. Furthermore, fermented material shows $\mathrm{pH}$ above 7 (Kowalczyk-Juśko and Szymańska, 2015).

According to Alburquerque et al., (2012) in the digestate based on manure and various

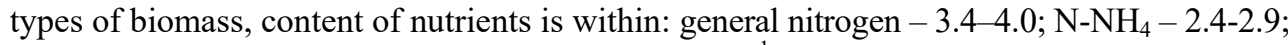
$\mathrm{P}-0.8-1.2 ; \mathrm{K}-2.7-3.1-\left(\right.$ values were provided in $\left.\mathrm{g} \cdot \mathrm{l}^{-1}\right)$.

Digestate in relation to the final destination is subjected to further treatment which the most often included mechanical dehydration, oxygen stabilization and packaging (Kowalczyk-Juśko and Szymańska 2015).

Due to the increase in the number of modern biogas plants in Poland - from 8 in 2008 to 83 in 2016 (data acc. to the Register of Agricultural Biogas Producers maintained by the President of the Agricultural Market Agency - as of 4th November 2016) the amount of digestate for use increases. Presently, resources of its dry mass are estimated at 172 thousand tonnes annually. The amount of digestate produced by a single biogas plant is difficult for local use. The research carried out by Dohler and Schliebner (2006) show that transportation of non-processed digestate at the distance bigger than $10 \mathrm{~km}$ from the place of production is non-profitable if it is going to be used for fertilization purposes. It is reasonable since the liquid fraction as well as solid of digestate include nitrogen both in the organic and non-organic form (Vismara et al., 2011; Riva et al., 2016). It limits the possibility of dosing digestate to soil according to the European Nitrogen Directive (1991) which defines the annual limit of dosing nitrogen up to 170 kilo per one hectare of a plantation. This limit reduces profits of agricultural biogas owners which use manure (main source of nitrogen in the digestate) as an inhibitor of methane fermentation process. Biogas owners are forced to pay receivers for utilization of digestate or to lease respectively big acreages in order to distribute these residues and leave border fertilization doses.

In relation to the above, another, economically justified method of using digestate for fertilization purposes is searched for. One of such methods is production of granular organic and mineral fertilizers based on digestates and mineral substance. Fly ash from professional energy industry installations, which combust pure biomass, seems to be the best addition in this process. In Poland, as a result of pro-ecology actions, in the recent years many energy units heated only with biomass have been founded e.g. "Zielony blok" in Połanice power plant. According to the literature, ash from biomass combustion may be successfully used as fertilizer (Huang et al., 2014). Good fertilization results may be also achieved from mixtures of ash with organic substances (Ram and Masto, 2014; Kumar et al., 2015). On account of origin, these materials have varied physical properties such as: size distribution, density, porosity. According to the research concerning biomass (Mudryk and Wróbel, 2011; Wróbel et al., 2013) these properties, except for process parameters significantly influence the quality of obtained granulates. A degree of fineness influences the process of providing material to a granulator and on the density of obtained granulates (Mudryk and Wróbel, 2012; Maj and Kuranc, 2014). A considerable participation of fine fractions in raw material influences the improvement of the quality and durability of granules (Mani et al., 2006; Karbowniczak et al., 2015). However, considerable fineness causes reduction of durability and increases the expenditures incurred on the granulation 
Impact of selected properties...

process (Frączek et al., 2010). Thus, one should assume that properties of the investigated raw materials will also affect their granulation process and their mixtures and as a result the parameters of obtained granulates.

In relation to the above, the main objective of the research is to determine the impact of basic physical properties of digestates and ash on density and tensile strength of granular fertilizers obtained from the mixtures of these substrates.

\section{Material and methodology of research}

Digestate from biomass plants located in Piekoszów and Sobawiny and fly ash from biomass combustion in Połaniec power plant, which has a nominal upper size of a grain $d_{95}$ below $0.25 \mathrm{~mm}$.

Moisture, grain composition, real density, envelope density, bulk density and porosity were determined for the digestate. Ash was described by determination of its moisture, real density and bulk density and general porosity.

So characterized material was used for preparation of mixtures, from which samples of granular fertilizers were made. The following were added to the investigated digestate: 25 , 50 and $75 \%$ of ash (mass participation referred to dry mass of materials) and were mixed in a laboratory mixer. These mixtures were determined with codes A25, A50 and A75 (mixtures based on the material from Piekosz) and B25, B50 and B75 (Sobawiny). Additionally, as reference samples, granulation of clean research material marked with the following codes was carried out: ash - A0; digestate from Piekoszów - A100 and from Sobawiny - B100. Moisture of mixtures was set at the level of $15 \%$, pressure of agglomeration was $200 \mathrm{MPa}$. Granulation was carried out with the use of a test machine EDZ20 equipped with an attachment with a closed chamber, which allows obtaining granules with $12 \mathrm{~mm}$ diameter. The obtained granulates were assessed and their envelope density, compaction degree $I_{D}$, compaction index $I_{S}$ and pressing tensile strength $R c$ were determined.

Moisture was measured pursuant to the standard PN-EN ISO 18134-1:2015-11. In order to make the measurement of the particle size distribution and density possible, samples from biogas were dried and measurements were carried out on the material with analytical moisture of $7.5 \%$. Reduction of moisture to the above level allowed minimization of the moisture impact on the formation of aggregates from material fractions. Measurements were carried out in three iterations for each of the tested samples and analysis of results was carried out on the averaged values.

Measurements of the particle size distribution of digestate were carried out on the material in such condition in which it was provided (non-fragmented). The measurement was carried out according to the requirements of the standard PN-EN ISO 17827-2:2016-07 using the set of screens comprising (from the top) the slotted screen with a diameter of meshes of $3.15 \mathrm{~mm}$ and braided screens, whose side of the square was: $2.8 ; 2 ; 1.4 ; 1 ; 0.5$; $0.25 \mathrm{~mm}$. The sample consisted of $150 \mathrm{~g}$ of the investigated material. Sieving was carried out on a laboratory shaker LPzE-4e by Morek Multiserw company. Based on the initial test the following parameters of the shaker operation were determined: amplitude 0.1; frequency 50; test duration $60 \mathrm{~s}$. Based on the mass of the material remaining on particular 
screens, weighted with precision up to $0.01 \mathrm{~g}$, a percentage participation of the fraction in the sample and the median value of the particle size distribution were determined $d_{50}$.

Absolute density of raw materials was measured with the use of a gas pycnometer AccuPyc 1340 by Micrometrics company (working gas - helium).

Envelope density of raw materials, mixtures and granulates was measured with GeoPyc 1360 by Micromterics which measures density with the quasi-liquid pycnometry method. The device measures the envelope volume of solid material placed in the measuring chamber with the use of powder with granulation below $0.25 \mathrm{~mm}$. The use of powder instead of liquid allows elimination of material moistening phenomenon (soaking) which allows testing materials which indicate high absorbency. Based on the measurements of absolute and envelope density, internal porosity $p_{W}$ of digestate was determined.

Bulk density of the investigated raw material and their mixtures was measured pursuant to the guidelines of standard PN-EN ISO 17828:2016-02 with the use of a container with volume of $5 \mathrm{dm}^{3}$. Based on the measurements of bulk and envelope density, external porosity $p_{Z}$ of digestate was determined.

For the obtained granulates the compaction degree $I_{D}$ was determined as a relation of envelope density of granules to the bulk density of fragmented material which indicates multiplicity of bulk density of material in comparison to the granules density and compaction index $I_{S}$ as a relation of envelope density of granules to the absolute density of material which shows how density of granules approaches the absolute density of raw material.

Tensile strength of granules to compression $R c$, was determined according to the Brazilian method which is a variety of compression static test which allows testing samples which are roll-shaped by pressing force along the diameter of granules. Course of compression was carried out till the sample broke. Tensile strength to compression was determined according to the following relation:

where:

$$
\mathrm{Rc}=2 \cdot \mathrm{F} \cdot(\pi \cdot \mathrm{D} \cdot \mathrm{L})^{-1}
$$

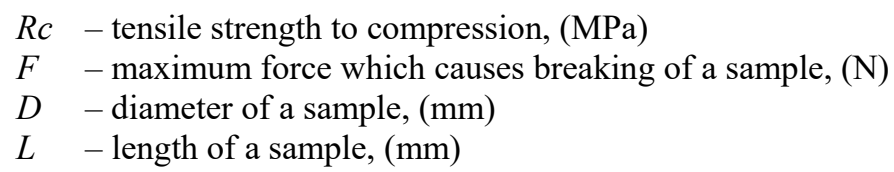

\section{Research results}

Research material had moisture at the level of $75.5 \%$ - digestate from biogas plant Piekoszów, $71.4 \%$ - digestate from Sobawiny and 6.3\% ash from Połaniec power plant. Figure 1 presents results of the measurement of grain composition. The diagram presents average results of the percentage participation of particular fractions in digestate samples from Sobawiny and Piekoszów.

Particle size distribution of the sample from Sobawiny has the highest participation of the fraction above $3.15 \mathrm{~mm}(28 \%)$ and the fraction remaining on a $0.5 \mathrm{~mm}$ screen $(24.4 \%)$ and minimum participation of fraction which remains on a $2 \mathrm{~mm}$ screen (1.6\%) and fraction of dust (3.8\%). 
Impact of selected properties...

In case of the sample from Piekoszów, the biggest fraction with regard to dimensions constitutes only $8.6 \%$ and the highest percentage participation is in case of the fraction which remains on $1.4 \mathrm{~mm}$ screen $(26.4 \%)$ and the fraction, where particles are bigger than $0.5 \mathrm{~mm}(21.3 \%)$. The finest fraction constitutes the lowest participation (4.4\%). In both cases, the fraction which remains on the $2.8 \mathrm{~mm}$ screen was omitted, which may result from a small difference in the previous screen $(3.15 \mathrm{~mm})$ that is only $0.35 \mathrm{~mm}$ and the fact that the $3.15 \mathrm{~mm}$ screen has round meshes and $2.8 \mathrm{~mm}$ screen has square meshes, where a diagonal of the square is close to $3.9 \mathrm{~mm}$.

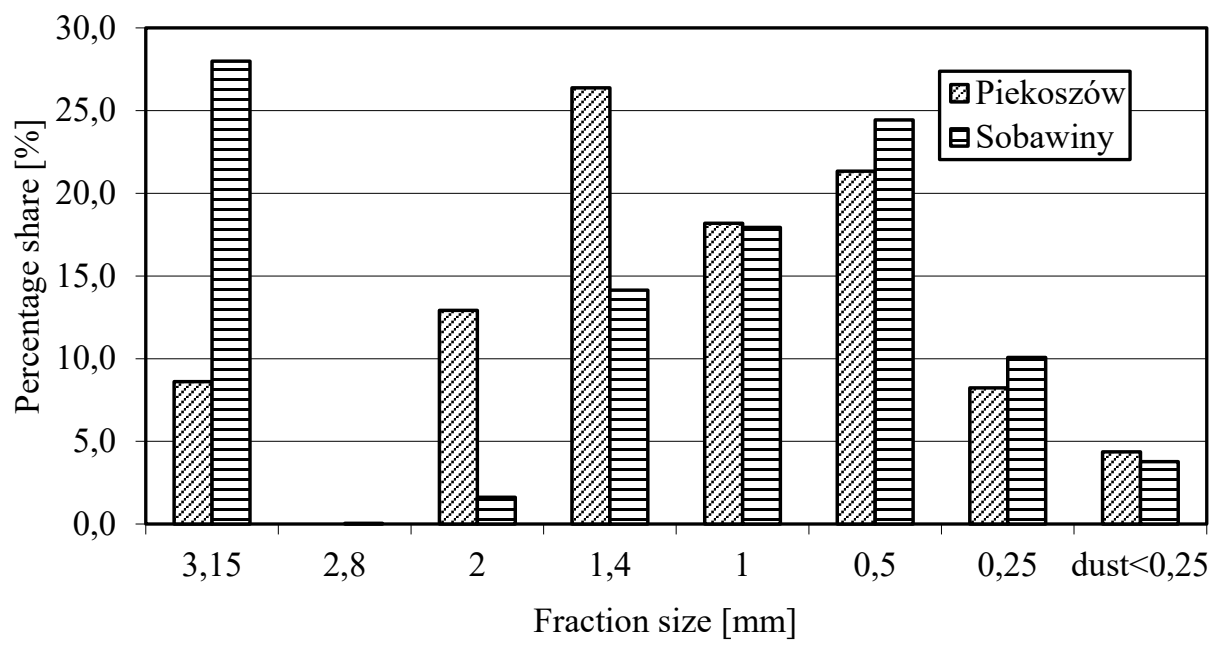

Figure 1. Percentage share of particular dimensional fractions of particles in digestate samples from Sobawiny and Piekoszów

A clear difference between the investigated materials may be reported when comparing participation of the biggest fraction, whose participation in case of digestate from Piekoszów is 3 times lower in comparison to the post-fermentation mass from Sobawiny. On the other hand, the following fractions i.e. which remain on the 2 and $1.4 \mathrm{~mm}$ screens clearly have higher participation in the sample of digestate residues from Piekoszów ( $2 \mathrm{~mm}$ almost 8-times higher, $1.4 \mathrm{~mm}$ almost 2-times higher). The total participation of those three biggest fractions is similar and is $42.7 \%$ for Sobawiny and $47.9 \%$ for Piekoszów. The remaining fractions have a similar participation for the investigated materials. A diagram in figure 2 which presents cumulative distribution of particle size, that is the sum of subsequent fractions remaining on a given screen, confirms the above observations. Moreover, the indicated central value of the particle size $d_{50}$ at the level of 1.26 (Sobawiny) and 1.35 (Piekoszów) indicates that these materials with regard to the particle size distribution differ only slightly and this difference occurs in the fraction participation whose grain dimension is more than $1.4 \mathrm{~mm}$. 
M. Wróbel, J. Frączek, M. Jewiarz, K. Mudryk, K. Dziedzic

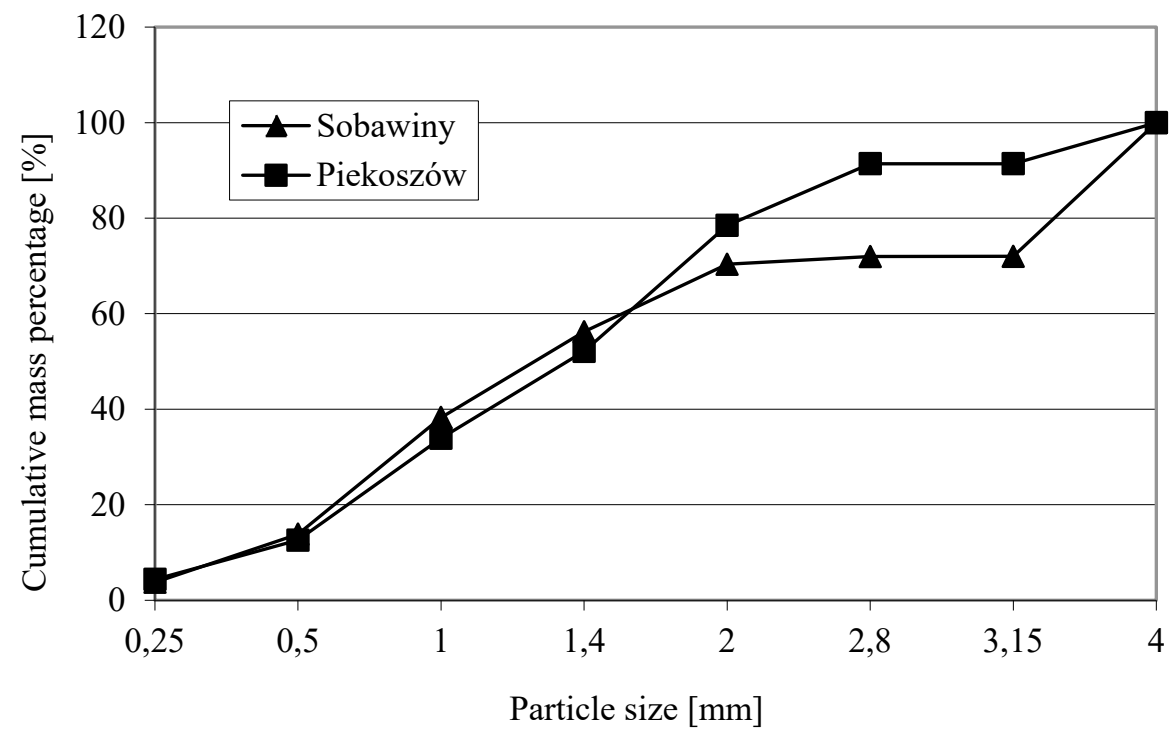

Figure 2. Cumulative particle size distribution in digestate samples from Sobawiny and Piekoszów

The presented size distribution may affect the process of granulation of mixtures of digestate with ash. A considerable participation of the fraction whose particles size is more than $3.15 \mathrm{~mm}$ in the sample from Sobawiny may be problematic. In case of granulation on plate granulators where the obtained average diameter of granules is within few millimetres, this fraction may cause difficulties in obtaining appropriate granules and may cause the need to mill this raw material before the process of agglomeration.

The determined absolute density of digestate was $1.35 \mathrm{~g} 1,35 \mathrm{~g} \cdot \mathrm{cm}^{-3}$ (Sobawiny) and $1.41 \mathrm{~g} \cdot \mathrm{cm}^{-3}$ (Piekoszów) while ash had absolute density of $2.47 \mathrm{~g} \cdot \mathrm{cm}^{-3}$. Values of envelope density and bulk density of the investigated materials were presented in table 1.

The value of absolute density of dry material in both cases is at a similar level but density of digestate from Piekoszów biogas plant is higher. Values of envelope density of both materials differ which may have a direct relation to a different structure of the material. Digestate from Piekoszów biogas station formed numerous crumbs with pores where test powder could not permeate. On the other hand, more loose structure of the digestate from Sobawiny caused that the medium penetrated the material more precisely. This observation is confirmed by the value of porostiy which is higher for the digestate from Piekoszów 
Impact of selected properties...

Table 1.

Values of parameters of the investigated raw materials in dry state

\begin{tabular}{lccc}
\hline Material & Sobawiny & Piekoszów & Ash \\
\hline Absolute density, $\left(\mathrm{g} \cdot \mathrm{cm}^{-3}\right)$ & 1.35 & 1.41 & 2.47 \\
Envelope density, $\left(\mathrm{g} \cdot \mathrm{cm}^{-3}\right)$ & 0.28 & 0.23 & - \\
Bulk density, $\left(\mathrm{g} \cdot \mathrm{cm}^{-3}\right)$ & 0.08 & 0.09 & 0.46 \\
Internal porosity, $(\%)$ & 79.2 & 83.7 & \\
External porosity, $(\%)$ & 71.4 & 60.6 & - \\
Total porosity, $(\%)$ & 94.1 & 93.6 & 81.2 \\
\hline
\end{tabular}

In the process of granulation, digestate constitutes a basis which forms a skeleton of a granule, filled with ash particles $(\mathrm{d}<0.25 \mathrm{~mm})$. Based on the above assumption and obtained data, it was determined what maximum mass participation of ash may be added to the investigated digestate so that it is in a free space between the particles of digestate. For the residues from Piekoszów $I_{\max }$ it is $75.6 \%$ and for the residues from Sobawiny it is as much as $80 \%$. It is a theoretical value, which cannot be achieved in reality which is confirmed by the results of the measurement of the bull density of ash mixtures with digestate presented in figure 3.

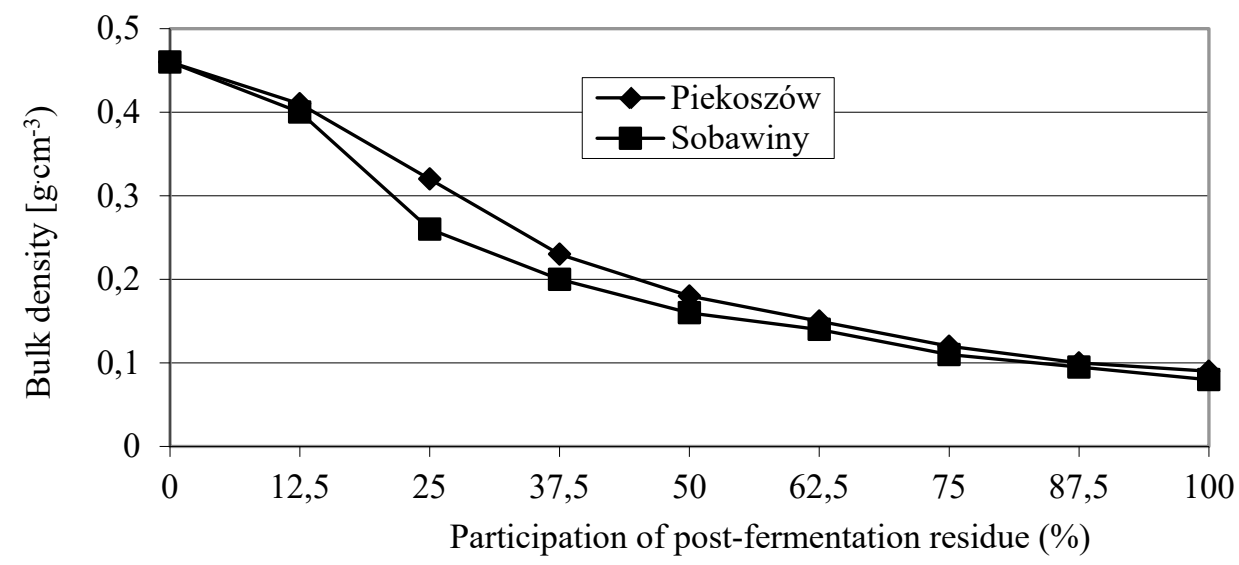

Figure 3. Bulk density of raw materials and tested mixtures 
For the obtained granulates (Fig. 4) envelope density, compaction index and compaction degree were determined. The obtained results were presented in table 2 . The last described parameter was tensile strength of the obtained granules to compression, the results of measurement were presented in table 2 .

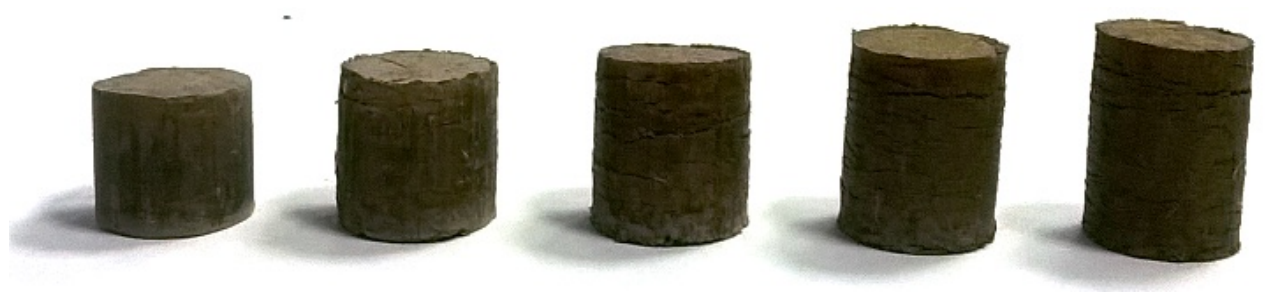

Figure 4. Samples of the obtained granulates (from the left A0 to A100) based on digestate from Piekoszów biogas plant

Table 2 .

The obtained values of parameters of granulates obtained based on the investigated digestate

\begin{tabular}{|c|c|c|c|c|c|c|c|c|c|}
\hline Sample code & A0 & $\mathrm{A} 25$ & A50 & A75 & A100 & $\mathrm{B} 25$ & B50 & B75 & $\mathrm{B} 100$ \\
\hline Envelope density, $\left(\mathrm{g} \cdot \mathrm{cm}^{-3}\right)$ & 1.88 & 1.18 & 1.03 & 0.91 & 0.85 & 1.11 & 0.96 & 0.90 & 0.81 \\
\hline Compaction index & 0,76 & 0.54 & 0.53 & 0.54 & 0.6 & 0.51 & 0.5 & 0.55 & 0.6 \\
\hline Compaction degree & 4.05 & 3.65 & 5.81 & 7.37 & 9.36 & 4.27 & 6 & 8.18 & 10.12 \\
\hline $\begin{array}{l}\text { Compression tensile } \\
\text { strength , (MPa) }\end{array}$ & 0.915 & 0.794 & 0.765 & 0.572 & 1.831 & 0.712 & 0.623 & 0.613 & 1.642 \\
\hline
\end{tabular}

\section{Conclusion}

Analysis of the obtained results allows the statement that differences between the investigated digestate result mainly from differences between the size and shape of particles which form a bed. Digestate from the biogas plant in Sobawiny has a higher, in comparison to digestate from Piekoszow, content of particles with the size more than $3.15 \mathrm{~mm}(28 \%$ in comparison to $8.6 \%$ ). However, taking into consideration the central value of grain size $d_{50}$ at the level of 1.26 (Sobawiny) and 1.35 (Piekoszów) one should state that these materials on account of grain size distribution differ only slightly and this difference occurs in the fraction participation whose grain dimension is more than $1.4 \mathrm{~mm}$. 
Impact of selected properties...

The obtained values of absolute and envelope density allowed determination of internal porosity of the investigated digestate substance, which for the digestate from Sobawiny is 79.2\% and for Piekoszów $83.7 \%$. Taking into consideration the size of particles, which comprise the ash bed (below $0.25 \mathrm{~mm}$ ) and external porosity of the investigated postfermentation residue (71.4\% Sobawiny and $60.6 \%$ Piekoszów) one should state that the investigated materials complete each other on account of grain composition. From the point of view of agglomeration, the determined value of external porosity of the investigated post-fermentation residue combined with the particle size distribution including particles above $1.4 \mathrm{~mm}$ (Sobawiny $42.7 \%$ and Piekoszów $47.9 \%$ ) causes that it constitutes a good skeleton material of formed fertilization granules while the smallest fractions and ash, which includes only small particles from $0.25 \mathrm{~mm}$, constitute a filling of granules. Values of envelope density of granulates based on the mixtures of digestate substances and ash higher than the envelope density of granulates obtained from clean digestate substances confirm the above. The determined compaction degree (lower for mixtures than in case of post-fermentation substances) also indicates that the compaction process of mixtures will be more effective. It is worth mentioning that the mixture with the code A25 has a lower value of compaction degree (3.65) and as the only one is lower than the value of the compaction degree for clean ash (4.05). It means that this mixture has the best particle size distribution with regard to dimensions.

Compaction index of granulates is lower in comparison to granulates from clean raw materials and oscillates within $0.5-0.55$. It is crucial information on account of rehydration processes of granules placed in soil. Results of the strength test which was carried out proved that all granulates obtained from mixtures have a lower tensile strength in comparison to granulates from pure components. Due to the sample size it was impossible to carry out the measurement of granules tensile strength to the crushing process PN-EN ISO 17831-1:2016-02. However, it should be taken into account in further research since this method better reconstructs destroying processes in a granule during transport and storage.

\section{Acknowledgement}

Research was funded by the National Centre for Research and Development and the National Fund for Environment Protection as a part of GEKON program - project no. GEKON1/05/214543/38/2015 "Proecology production of organic and mineral fertilizers based on waste: by -products of combustion and biogasification of biomass".

\section{References}

Agencji Rynku Rolnego: Rejestr Wytwórców Biogazu Rolniczego - stan na dzień 04.11.2016, http://www.arr.gov.pl/wytworcy-biogazu-rolniczego/rejestr-przedsiebiorstw-energetycznychzajmujacych-sie-wytwarzaniem-biogazu-rolniczego.

Alburquerque, J.A., Fuente, C., Ferrer-Costa, A., Carrasco, L., Cegarra, J., Abdad, M., Bernal, M.P. (2012). Assessment of the fertilizer potential of digestates from farm and agroindustrial residues. Biomass and Bioenergy 40, 181-189.

Bavutti, M., Guidetti, L., Allesina, G., Libbra, A., Muscio, A., Pedrazzi, S. (2014). Thermal stabilization of digesters of biogas plants by means of optimization of the surface radiative properties of the gasometer domes. Energy Procedia 45, 1344-1353. Doi:10.1016/j.egypro.2014.01.141. 
Döhler, H., Schliebner, P. (2006). Verfahren und Wirtschaftlichkeit der Gärrestaufbereitung. Darmstadt: KTBL.

Dyrektywa UE z dnia 12 grudnia 1991 r. dotycząca ochrony wód przed zanieczyszczeniami powodowanymi przez azotany pochodzenia rolniczego (91/676/EWG).

Frączek, J., Mudryk, K., Wróbel, M. (2010). Nakłady energetyczne w procesie brykietowania wierzby Salix viminalis L. Inżynieria Rolnicza, 3(121), 45-52.

Grinzi, G., Guidetti, L., Allesina, G., Libbra, A., Martini, P., Muscio, A. (2012). Increase of net power generation of biogas plants by reduction of heat loss. 20th European Biomass Conference and Exhibition.

Huang, X.J., He, N., Liu, M.D., Yang, D., Wang, Y. J. (2014). A Study on Release of Nutrients from Ash Fertilizer. Applied Mechanics and Materials 535, 523-527.

Karbowniczak, A., Wróbel, M., Rymar, J. (2015). Optymalizacja składu mieszanki biomasy rożnika i słonecznika wierzbolistnego na potrzeby procesu aglomeracji. Episteme 26, T.1, 255-263.

Kowalczyk-Juśko, A., Szymańska, M. (2015). Poferment nawozem dla rolnictwa. Fundacja na rzecz Rozwoju Polskiego Rolnictwa. Warszawa, ISBN 978-83-937363-6-2.

Kumar, T., Tedia, K., Devdas, D. (2015). Effect of fly ash combination with organic fertilizer on physico-chemical properties of soil. Journal of Progressive Agriculture, 6(1), 78-82.

Maj, G., Kuranc, A. (2014). Technologie produkcji oraz systemy certyfikacji jakości peletów $z$ biomasy roślinnej w: Wybrane problemy z zakresu ekoenergii i środowiska, Monografia Naukowa "Towarzystwo Wydawnictw Naukowych LIBROPOLIS" (red. W. Piekarski) Lublin, ISBN 978-83-63761-46-2.

Mani, S., Tabil, L., Sokhansanj, S. (2006). Effects of compressive force, particle size and moisture content on mechanical properties of biomass pellets from grasses. Biomass and Bioenergy, 30, 648-654.

Mudryk, K., Wróbel, M. (2011). „Briquetting and quality of Virginia mallow biomass briguettes ” Rozdział IV w: The acquisition and processing of biomass of Virginia mallow for energy purposes. (red. W. Piekarski). Wydawnictwo „Wieś jutra”, Warszawa, ISBN 978-83-62815-10-4.

Mudryk, K., Wróbel, M. (2012). Wpływ stopnia rozdrobnienia i ciśnienia aglomeracji na wybrane parametry jakościowe brykietu ze słonecznika wierzbolistnego. Autobusy, 13,10, 166-169.

PN-EN ISO 17827-2:2016-07 Biopaliwa stałe -- Oznaczanie składu ziarnowego paliw niesprasowanych -- Część 2: Metoda przesiewania wibracyjnego przy użyciu sit o wymiarach oczka 3,15 mm lub poniżej.

PN-EN ISO 17828:2016-02 Biopaliwa stałe -- Określanie gęstości nasypowej.

PN-EN ISO 17831-1:2016-02 Biopaliwa stałe -- Oznaczanie wytrzymałości mechanicznej peletów i brykietów -- Część 1: Pelety.

PN-EN ISO 18134-1:2015-11 Biopaliwa stałe -- Oznaczanie zawartości wilgoci -- Metoda suszarkowa -- Część 1: Wilgoć całkowita -- Metoda referencyjna.

Ram, L.C., Masto, R.E. (2014). Fly ash for soil amelioration: a review on the influence of ash blending with inorganic and organic amendments. Earth-Science Reviews, 128, 52-74.

Riva, C., Orzi, V., Carozzi, M., Acutis, M., Boccasile, G., Lonati, S., Adani, F. (2016). Short-term experiments in using digestate products as substitutes for mineral $(\mathrm{N})$ fertilizer: Agronomic performance, odours, and ammonia emission impacts. Science of The Total Environment, 547, 206-214.

Vismara, R., Canziani, R., Malpei F., Piccinini S. (2011). Biogas da agrozootecnia e agroindustria. Dario Flaccovio Editore s.r.1 ISBN 978-88-579-0020-9.

Wróbel, M., Frączek, J., Francik, S., Ślipek, Z., Mudryk, K. (2013). Influence of degree of fragmentation on chosen quality parameters of briquette made from biomass of cup plant Silphium perfoliatum L. Engineering for Rural Development Jelgava, Available at http://tf.1lu.lv/conference/proceedings2013/Papers/121_Wrobel_M.pdf 
Impact of selected properties...

\section{WPLYW WYBRANYCH WŁAŚCIWOŚCI SUROWCA NA CECHY JAKOŚCIOWE GRANULATÓW NAWOZOWYCH UZYSKANYCH Z MIESZANEK SUBSTANCJI POFERMENTACYJNEJ I POPIOŁU}

Streszczenie. W pracy przedstawiono wyniki badań, których celem było określenie wpływu składu ziarnowego i gęstości substancji pofermentacyjnej oraz popiołu na gęstość i wytrzymałość granulatów nawozowych, uzyskanych z mieszanek tych substratów. Wyznaczono skład ziarnowy, gęstość bezwzględną, gęstość pozorną oraz porowatość substratów. Wykonano granulaty nawozowe z czystych substratów oraz z ich mieszanek. Gęstość pozorna uzyskanych granulatów zawierała się $\mathrm{w}$ przedziale $0,81-1,88 \mathrm{~g} \cdot \mathrm{cm}^{-3}$. Wyznaczony stopień zagęszczenia zawierał się $\mathrm{w}$ przedziale 3,65-10,12. Natomiast wskaźnik zagęszczenia IS granulatów z mieszanek mieścił się w przedziale $0,5-0,55$ i był niższy w porównaniu do IS granulatów z substancji pofermentacyjnych $(0,6)$ i popiołu $(0,76)$.

Słowa kluczowe: popiół z biomasy, substancja pofermentacyjna, nawóz organiczno-mineralny, granulat nawozowy 